\title{
EDITORIAL
}

\section{INFRASTRUCTURAL EUROPE: EU LAW AND HUMAN LIFE IN TIMES OF THE COVID-19 PANDEMIC}

\section{Europa infraestructural: Derecho de la UE y vida humana en tiempos de la pandemia de Covid-19}

\author{
LOÏC AZOULAI \\ loic.azoulai@sciencespo.fr
}

Cómo citar/Citation

Azoulai, L. (2020).

Infrastructural Europe: EU law and human life

in times of the Covid-19 pandemic.

Revista de Derecho Comunitario Europeo, 66, 343-359.

doi: https://doi.org/10.18042/cepc/rdce.66.01

We have been living extraordinary times. This pandemic is characterized by the magnitude of its impact: universal in scope, breakneck in its propagation speed, uniquely intrusive in our everyday lives and minds. Yet, on another level, we have been living ordinary times. Over the last decade, Europe's "new normal" has been to face one crisis after another in a form of abnormality which has found expression in politics as decisionism (assisted by experts), in law as exceptionalism (in the form of states of emergency), and in mass and social media as polarisation (with a new kind of "infodemic"). ${ }^{1}$ At the European level, the manner in which current events have unfolded also sounds all too familiar. It is not so different from the sequence of events experienced during the crises of the last ten years: the first reactions by some

1 On exceptional legal arrangements following the Covid-19 outbreak, see Verfassungsblog, COVID 19 and States of Emergency, April 2020 (https://bit.ly/2BlZskD). 
Member States came in the form of non-cooperative behaviours, there was a clear lack of coordination with European relations falling apart, then an improved cooperation arose at the EU level with the Commission serving as a broker, convergences between some Member States led to partial agreements, and it eventually culminated in last minutes compromises involving most if not all Member States and the mobilisation by Union institutions of unconventional instruments "in a spirit of solidarity." This pattern emerged during the financial crisis in 2010, was repeated during the migration crisis in 2015 and is again observed following the Covid-19 outbreak. ${ }^{2}$

On one point, however, this crisis is different. This has to do with the revaluation of the role of the state. During the previous crises, states were under fire, somewhat humiliated, with some of them being accused of failing in keeping their finances or migration flows under control. This led to a further delegation of power to the European Union, to new forms of "executive federalism". ${ }^{3}$ This was justified by the need to restore the stability of the EU system as a whole (be it the financial system, the euro-area economic system, the common asylum system or the Schengen borders system). Instead, in the current crisis, everyone agrees that the state is at the centre of the stage. It is widely acknowledged that public health crises are to be managed at the national level. ${ }^{4}$ Faced with the pandemic and a widespread sense of disaster, the nation-state emerges as a particular form of "survival unit," one that is responsible for taking care of the population, identifying and protecting vulnerable groups, supporting the welfare system by keeping people in employment, or controlling the spread of the virus by enforcing new norms of social management. ${ }^{5}$ The state claims an uncontested responsibility towards and a privileged authority over its own population.

Where does the European Union stand in this context? On the one hand, the Union exposes the vulnerability of the Europeans' condition. The whole point of the EU machinery and legal order is to create interdependencies between Member States, mainly in the form of cross-border transactions and transnational social relationships, and to smoothly manage the consequences of this interdependence. ${ }^{6}$ However, close ties of interdependence generate

\footnotetext{
See Pacces and Wiemer (2020).

3 See, in relation to the Euro-crisis, Joerges (2014).

4 See recital 21 of Decision 1082/2013 of the European Parliament and of the Council of 22 October 2013 on serious cross-border threats to health.

5 The idea of the state as a "survival unit" was developed by Norbert Elias (2001). See, in relation to Europe, Joly (2007).

6 See de Witte (2018).
} 
negative externalities in case of infectious diseases. They are opportunities for a virus to spread. Transnational channels of communication are also chains of virus transmission. Moreover, that interdependence means that the satisfaction of our basic needs (food and healthcare) heavily rely on resources and means of production that our home state does not own nor controls. One the other hand, the Union works as an assistance provider. It provides assistance by lifting EU rules that impose constraints on national public spending and grants regulatory flexibility. True, these rules may be held responsible for the strain on healthcare resources and capacities in Member States in the first place. However, in this particular moment in time, the Union's relaxation of those rules has allowed for massive public intervention. ${ }^{7}$ Further, the Union guarantees state action by providing financial support from the EU budget and monetary policy support from the ECB. ${ }^{8}$ True, these guarantees are strictly targeted and conditional. Yet, they work as a rescuer for the worst hit countries. Throughout the pandemic, the Union thus appears to us in an ambivalent fashion: as a carrier of the virus and as a rescuer for the most vulnerable communities.

\section{EU LAW AND HUMAN LIFE}

This pandemic has revealed a special attachment to human life within European societies. This is reflected in the fact that, in an unprecedented move, most Member States governments took the decision to interrupt the economic cycle and terminate social life. For a limited period of time, absolute priority was given to human life. The state and society mobilized all of their economic and moral resources with the sole aim of preventing deaths and saving the dying. This trumped all other considerations relating to economic growth, social or individual preferences. For some national leaders, we were

7 See, in particular, Communication from the Commission, Communication on the activation of the general escape clause of the Stability and Growth Pact, COM(2020) 123 final, 20 March 2020; Communication from the Commission, Temporary Framework for State aid measures to support the economy in the current COVID-19 outbreak, 2020/C 91 I/01, 20 March 2020.

8 See, in particular, European Council, Report on the comprehensive economic policy response to COVID-19 pandemic, 9 April 2020; Eurogroup Statement on the Pandemic Crisis Support, 8 May 2020. See also ECB, ECB announces $€ 750$ billion Pandemic Emergency Purchase Programme (PEPP), 18 March 2020; ECB, Monetary policy decisions, 4 June 2020. 
"at war", for others this was "the greatest challenge since World War II." But what does this mean for the European Union and its law?

Human health is not absent from the EU law discourse. It is enshrined in the EU treaties as an overarching objective and a fundamental requirement. ${ }^{9}$ It features prominently in the case law of the European Court of Justice as a public interest, one that is a legitimate ground for national measures to derogate from EU law. In the 70s, the Court adopted the following striking formulation: "the health and life of humans rank foremost among the assets and interests protected by the Treaty." ${ }^{10}$ Human health is more than a discrete national interest to be respected; it is considered an essential common good protected by the Union as a whole. This may seem a curious expression for the European Union whose competences are notoriously limited in relation to the protection of health. ${ }^{11}$ Yet, it has become commonplace in the Court's case law.

This expression makes sense in the context of a broader discourse which aims to express respect for the sensitive nature of state regulation in this field, while embedding it into the EU approach to economic integration. On the one hand, it means that Member States are solely responsible for setting the level of protection they wish to maintain and the best way to attain it. ${ }^{12}$ But, on the other hand, it means that health cannot be dissociated from "wealth" of the continent. Health protection is to be put into balance with, and sometimes be subjected to, competing objectives: the functioning of the internal market, the pursuit of economic growth or the sustainability of national public finances. ${ }^{13}$ This balancing exercise is clearly reflected in the case law of the European Court of Justice in the area of internal market. Thus, for example, it may be accepted that a system of priority supply

9 See Arts. 6(a), 9 and 168 (1) Treaty on the Functioning of the European Union, and Art. 35 of the EU Charter of Fundamental Rights.

10 Judgment of the Court of 19 May 2009, Apothekerkammer des Saarlandes and others, Joined Cases C-171/07 \& C-172/07, EU:C:2008:729, par. 19; See already Judgment of the Court of 20 March 1976, de Peiper, Case 104/75, EU:C:1976:67, par. 15.

11 As stated in Art. 6 TFEU, the competence of the EU in the health field is a complementary competence limited to "actions to support, coordinate or supplement the actions of the Member States". This is reflected in the legal basis of Art. 168 TFEU. Only the area of "common safety concerns in public health" is an area of shared competence (Art. 4(2) k TFEU).

12 Judgment of the Court of 19 May 2009, Apothekerkammer des Saarlandes and others, Joined Cases C-171/07 \& C-172/07, EU:C:2008:729, par. 19.

13 On the economic-oriented approach of the Commission, see Commission staff working document, Investing in Health, SWD (2103) 43 final, 20 February 2013. 
in human blood and human plasma "is achieved through the pursuit by each Member State of a national objective of self-sufficiency." ${ }^{14}$ This does not mean, however, that Member States are allowed to protect domestic producers. They are required to look for "the least detrimental solution to the free movement of goods, having regard in particular to the fact that the medicinal products are supplied to hospitals against payment of an amount corresponding exclusively to their production costs." ${ }^{15}$

In Covid-19 times things are different. The lives and health of national citizens is the "paramount consideration." tionate" barriers to free movement and "unsustainable" public expenditures aimed at maintaining hospital services that are accessible to all. Are the EU and its law equipped to cope with this abrupt shift? What this shift involves is a complete transformation in the self-understanding of the Union and its law. For some years now, European leaders have been embracing the notion that the Union's institutions, policies and laws have as their main purpose "the promotion of the European way of life" and "the well-being" of the peoples of the Union (Azoulai, 2020). By this they mean the pursuit of specific public goods and the protection of certain common values. ${ }^{17}$ However, in the pandemic context, the issue cannot just be about "ways of life" and "well-being"; it is about life in the broadest sense. This refers to the swarm of human and non-human lifeforms that make up the ecosystem in which the virus circulates and operates, as well as to the material conditions of life in terms of basic needs of people and social relationships. In a context where human lives are threatened, the Union cannot be reduced to a basis for the creation of public goods. If that were the case, the very notion of Europe as a guarantee of existence for Europeans would be destroyed.

At this particular moment in the history of European integration, the Union is bound to turn itself into an infrastructural good, set up for the very purpose of establishing adequate platforms aimed at ensuring the preservation of life and keeping adequate infrastructures from being destabilised or decimated. ${ }^{18}$ The condition of being European is thereby changed. It is no longer simply about living under material and moral conditions that allow

14 Judgement of the Court of 8 June 2017, Medisanus, C-296/15, EU:C:2017:431, par. 89.

15 Ibid., par. 99.

16 Communication from the Commission, Towards a phased and coordinated approach for restoring freedom of movement and lifting internal border controls, C(2020) 3250 final, 13 May 2020.

17 See Walker (2017).

18 The notion of infrastructure is borrowed from Edwards (2003). 
for a mobile and decent life in Europe (Editorial Comments, 2017). Being European means living and surviving within and by means of a resilient network of vital infrastructures.

\section{INFRASTRUCTURAL EUROPE}

What we have come to realise during this pandemic is "the interdependent character of our bodily and social lives" (Butler, 2020). We now know that our survival depends on our relationships with others on a day-to-day basis: it depends on the objects we touch, on the air they exhale. But we have also realised that human life is dependent upon infrastructures, social and technological systems that are at risk of being overloaded, congested or decimated. These infrastructures and systems often belong to or are controlled by the state. But, faced with such exceptional circumstances, the state appears to be in need of support. Europe is there to provide this support. It comes in the form of ensuring the conditions without which vital infrastructures and social systems cannot fulfil their function. This is the meaning of "infrastructural Europe."

Interestingly, the Covid-19 outbreak prompted the UK government to seek access to EU health cooperation. ${ }^{19}$ This once again shows that the widespread desire for independence in today's Europe comes up against the fact that the existence of Europeans depends, to a large extent, on a set of interconnections that are institutionally guaranteed by the European Union. These interconnections are all the more vital when lives are at stake. On the other hand, it should be cautioned that this is the expression of a certain conception of human life. The centrality of infrastructures for sustaining life is not necessarily recognised in the rest of the world (Edwards, 2003).

What then are these infrastructural conditions? The demand for infrastructural support takes on three main forms. The first is a demand for knowledge. The pandemic has made clear that the life of Europeans is largely dependent on the production of scientific knowledge (Glaser, forthcoming). This mainly concerns diagnostic tests, medical treatments, the search for a vaccine and the development of modelling methods on virus spread. This calls for the setting up of "knowledge infrastructures", i.e. networks of researchers and institutions that generate, share and maintain specific knowledge about the coronavirus disease (Edwards et al., 2013). It has become clear that

19 The Guardian, UK seeks access to EU health cooperation in light of coronavirus, 2 may 2020. 
these networks cannot be handled nationally. Faced with a global pandemic and a "highly dynamic epidemiology", transnational and supranational forms of coordination are needed (Eichler et al., 2020). Thus the European Commission set up a platform to enable the collection and sharing of research data. ${ }^{20}$ It helped to coordinate research infrastructures funding and to get new funding for research. ${ }^{21}$ Finally, it launched the ERAvCorona action plan to extend and support large EU clinical trials for the clinical management of Coronavirus patients. EU agencies such as the European Medicines Agency and the European Centre for Disease Prevention and Control as well as private consortia such as the European Clinical Research Infrastructures Network and the Coalition for Epidemic Preparedness Innovations were involved in this action. ${ }^{22}$ Despite these efforts, the clinical trial supported by the EU, called Discovery, was not a success. This was allegedly due to a lack of regulatory flexibility and coordination. ${ }^{23}$

The second form of infrastructural intervention concerns healthcare capacities. The Member States' healthcare systems, and in particular the hospital infrastructures, have been severely strained by the pandemic. Sometimes it looked as if the main concern of the national and European authorities was not directed towards preserving life and preventing human suffering. Rather, it was about ensuring the resilience of state capacities. But this is a misleading view. In Europe, the vision that human life depends upon its infrastructural conditions of care and support is deeply rooted in society. At the EU level, this was reflected in two series of actions. First of all, the EU acted to protect the financing capacity of the healthcare systems in the Member States. The Commission reactivated the Emergency Support Instrument, ${ }^{24}$ support to Member States has been proposed through the Coronavirus Response Investment Initiative, and the EU Solidarity Funds have been mobilised with, in particular, the purpose of "restoring the working order of infrastructure" in the field of health. ${ }^{25}$ Second, the EU acted to maintain the

20 See: https://www.covid19dataportal.org.

21 See: https://bit.ly/38fmFBk.

22 See Regulation 851/2004 of the European Parliament and of the Council of 21 April 2004 establishing a European Centre for disease prevention and control.

23 EMA's Rasi laments fragmented clinical trial efforts targeting COVID-19, at https://bit. ly/3gafdKl.

24 See Council Regulation 2020/521 of 14 April 2020 activating the emergency support under Regulation 2016/369, and amending its provisions taking into account the COVID-19 outbreak.

25 See Regulation 2020/461 of the European Parliament and of the Council of 30 March 2020 amending Council Regulation 2012/2002 in order to provide financial 
availability of medical equipment as well as hospital and IT infrastructure. This entailed facilitating national public procurement procedures, empowering the Commission to procure on behalf of the Member States ${ }^{26}$ setting up platforms that facilitate the identification of available supplies and their matching with demand by Member States, ${ }^{27}$ centralising the emergency stockpiling of medical equipment and its distribution, as well as creating a strategic stockpile via rescEU and the Emergency Response Coordination Centre. ${ }^{28}$

Essential in pandemic times is the operation of integrated supply chains and production lines. This is the third dimension of infrastructural Europe. As stated by the Commission, the preservation of supply chains is "crucial to maintain availability of goods, in particular of essential goods such as food supplies including livestock, vital medical and protective equipment and supplies" (European Commission, 16 March 2020a: 1). The fact that supply chains have been disrupted due to global shortage of critical goods and trade and movement restrictions introduced within the European Union territory by the Member States has generated a twofold reaction from the European Union. ${ }^{29}$ First of all, the Commission has imposed export restrictions on personal protective equipment. ${ }^{30}$ For a period of six weeks, an authorisation was required for the export of critical material outside the Union, whether or not originated in the Union. Second, action was taken to subject export bans and entry bans introduced by Member States to a common legal framework (European Commission, 16 March 2020a). With a view to ensuring the smooth flow of goods along the trans-European transport network, the Commission recom-

assistance to Member States and to countries negotiating their accession to the Union that are seriously affected by a major public health emergency.

26 See Council Regulation 2020/521 of 14 April 2020 activating the emergency support and Guidance from the European Commission on using the public procurement framework in the emergency situation related to the COVID-19 crisis (2020/C 108 I/01), 1 April 2020.

27 This is the COVID-19 Clearing House for medical equipment. See also the European Cluster Collaboration Platform supported by the Commission.

28 See Commission Implementing Decision 2020/414 of 19 March 2020 amending Implementing Decision 2019/570 as regards medical stockpiling rescEU capacities.

29 See Communication from the Commission, Coordinated economic response to the COVID-19 Outbreak, COM(2020) 112 final, 13 March 2020.

30 See Commission Implementing Regulation 2020/402 of 14 March 2020 making the exportation of certain products subject to the production of an export authorisation. 
mended designating some internal border-crossing points as "green lane" border crossings open to all freight vehicles. ${ }^{31}$

\section{THE RESTRUCTURING OF THE EUROPEAN SOCIAL SPACE}

The positioning of the Union and its law as a provider of infrastructural conditions bears consequences on the structuring of European societies. It both contributes to the persistence of a social world based on specific protections and exclusions, and to the emergence of a new perception of the European social space.

To begin with, this world pandemic has strengthened the assertion of the Union as a "local community" (Marzal, 2020). This is illustrated by the unprecedented repatriation effort made by the Union's institutions. The Union helped Member States to organise repatriation flights for tourists from their own countries and other European states. ${ }^{32}$ At the same time, the Commission's Emergency Coordination Centre, which is part of the EU Civil Protection Mechanism, coordinated repatriation operations for EU citizens and citizens from "partner countries". ${ }^{33}$ In exceptional situations in which the existence of Europeans is challenged, the Union is inclined to offer a communal form of protection. This strikingly parallels the case law of the European Court of Justice offering protection to Union citizens subject to extradition to countries where they are at risk of being deprived of basic standards of European life..$^{34}$ In both cases, the Union operates as a support mechanism for ensuring that Member States' authorities will cooperate among themselves and with the EU institutions.

Moreover, EU Covid-19 law confirms the divides structuring the European social space. First of all, the impact of the crisis on countries will be deeply asymmetric, with the worst hit countries being those dependent on large tourism, retail services sectors, a high number of small business and air transport, in which remote work is less feasible, and where the capacity to access

31 Communication from the Commission on the implementation of the Green Lanes (2020/C 96 I/01), 24 March 2020.

32 These operations are governed by Council Directive 2015/637 of 20 April 2015 on the coordination and cooperation measures to facilitate consular protection for unrepresented citizens of the Union in third countries.

33 See Decision 1313/2013/EU of the European Parliament and of the Council of 17 December 2013 on a Union Civil Protection Mechanism.

34 See especially Judgment of the Court of 6 September 2016, Petruhhin, Case C-182/15, EU:C:2016:630. 
credit on capital markets is the weakest (Dani et al., 2020). In this context, the relaxation of regulatory and budgetary constraints for all Member States is likely to widen disparities and deepen inequality among Member States. Second, the instruments introduced by the EU to respond to the socio-economic impact of the outbreak are likely to perpetuate inequality in distributional outcomes among social groups within Member States. Such mechanisms create opportunities for some, and risks for others. This point is well illustrated by the financial instrument called SURE which stands for Support to Mitigate Unemployment Risks in an Emergency. ${ }^{35}$ This instrument provides financial assistance in the form of loans aimed at supporting schemes activated by Member States to help people who have lost their income. This kind of mechanism is designed to ensure the protection of workers and self-employed people in the workplace. However, it does not have any bearing on precarious workers, seasonal workers working in other Member States, the black working population, or the youth. As regards the latter, its is worth recalling that, following the Euro-crisis, the European Commission already urged that the youth was becoming a "lost decade" due to their low implication in the labour market and weak social integration (European Commission, 2010: 9). At the time, some mitigation mechanisms were enacted. However, they went along with austerity policies and structural reforms that rendered the youth even more vulnerable (Steiert, 2019). Moreover, it should be noted that, in the pandemic context, the EU is deprived of its favourite strategy for dealing with the impact of the economic crisis on the youth, i.e. the promotion of economic migration and labour mobility.

But infrastructural Europe is not only confirming pre-existing trends. It unveils social positions that were previously largely overlooked. This is true in relation to people who fulfil functions essential to ensuring a continuous flow of goods and services. These are the carers, carriers, cashiers, cleaning women and men, drivers, healthcare workers, domestic workers. Those, for whom remote work and teleworking were hardly feasible, were actually the most exposed to occupational risks during the pandemic. ${ }^{36}$ This class of people somewhat echoes the "yellow vests movement" that formed in pre-Covid-19 France (Confavreux, 2019; Genestier, 2019). That movement concerned people who perceived themselves as being the most exposed to the downsides of globalisation and urbanisation. Their uprising was first of all a movement of

35 Council Regulation 2020/672 of 19 May 2020 on the establishment of a European instrument for temporary support to mitigate unemployment risks in an emergency (SURE) following the COVID-19 outbreak.

36 See: https://bit.ly/38cNkP4. 
people playing a critical role in society - skilled and unskilled workers, nurses, taxi drivers... - pursuing the satisfaction of basic pressing needs such as access to essential services, transport and decent housing conditions. However, the social position of this group of people has long been blurred by the Union and its policies which tend to focus on the fight against poverty and social exclusion (Hugrée, Penissat et Spire, 2017: 53).

These notions of "essential needs" and "critical functions" re-emerged during the pandemic. They now have a tangible existence in law and policy. At the EU level, this is reflected in the field of free movement and border controls. Member States were requested to carve out exceptions to travel restrictions between Member States that were deemed legitimate to protect the public health of populations. This was to permit and facilitate "emergency transport services", "the circulation of essential products", and "the crossing of frontier workers, in particular those working in the health care and food sector, and other essential services (e.g. child care, elderly care, critical staff or utilities)" (European Commission, 16 March 2020a). ${ }^{37}$ Similarly, whilst recommending temporary restrictions on non-essential travels from third-countries into the EU, the Commission clarified that this "should not apply to travellers with an essential function or need" (European Communication, 16 March 2020b). Third country nationals exempted from the travel ban include the "infrastructural workers" (healthcare professionals, heath researchers, elderly care professionals, frontier workers, transport personnel engaged in haulage of goods, military personnel and humanitarian aid workers), as well as vulnerable persons in need of protection (passengers travelling for imperative family reasons, persons in need of international protection or for other humanitarian reasons). In hostile times for free movement, EU law has worked out a distinctive form of mobility oriented towards the preservation of the health of non-mobile populations. ${ }^{38}$ The result is the emergence of a new class of Europeans.

37 It should be reminded that free movement rights may be restricted on grounds of public health provided the safeguards laid down in Art. 29 of Directive 2004/38 are guaranteed. See Directive 2004/38/EC of the European Parliament and of the Council of 29 April 2004 on the right of citizens of the Union and their family members to move and reside freely within the territory of the Member States. See also Thym (2020).

38 This is borne out by the fact that the lifting of travel restrictions should be essentially based on the "epidemiological situation in the Member States or sub-national areas" (Communication from the Commission, Towards a phased and coordinated approach for restoring freedom of movement and lifting internal border controls, C(2020) 3250 final, 13 May 2020). 
But, in Europe, there still remains a group of people that are treated as separate despite living among us. The pandemic made the separation imposed on migrants even more visible. Most vulnerable groups within the European population - elderly and people suffering from chronic diseases — were recognised. ${ }^{39}$ Special techniques of social management aimed at protecting them, such as social distancing measures, were fashioned (Alemanno, 2020). The Commission went as far as to offer assistance to organise the transfer of patients from Member States where the capacities of health systems were under great stress to Member States where intensive care places were available. ${ }^{40}$ Infrastructural solidarity was at work to save Europeans' lives. Instead, migrants were left to their fate. Special measures were taken but only with the aim of containing them. Some Member States closed facilities such as arrival centres for asylum seekers, migration camps were placed under lockdown, ${ }^{41}$ rescue operations and resettlement programmes were suspended (European Union Agency for Fundamental Rights, 2020). The result was heightened vulnerability for migrants in Europe.

The irony is that social distancing, identification, screening, risk-analysis and transfers are not unknown to migrants. These are accepted techniques under EU law. They reflect the fact that migrants, especially illegal migrants, are mostly seen as a threat (a cultural, not biological threat) to be placed in the hands of institutions and institutional cooperation (Azoulai, 2018). As a result of EU migration law, migrants are put at a distance from "us" and "our societies", even if granted a legal status and whilst living among us, with almost no possibilities to move and limited opportunities to develop social relationships. The Guidance on the implementation of relevant EU migration law provisions published by the Commission in April 2020 only exacerbated

39 See European Commission, Joint European Roadmap towards lifting COVID-19 containment measures, 8 April 2020, p. 11.

40 See Communication from the Commission, Guidelines on EU Emergency Assistance on Cross-Border Cooperation in Healthcare related to the COVID-19 crisis, C(2020) 2153 final, 3 April 2020. This is an extension of the Cross-Border Healthcare Directive and Social Security Coordination Regulation: Directive 2011/24 of the European Parliament and of the Council of 9 March 2011 on the application of patients' rights in cross-border healthcare; Regulation 883/2004 of the European Parliament and of the Council of 29 April 2004 on the coordination of social security systems. See, by way of illustration, Judgment of the Court of 9 October 2014, Petru, C-268/13, EU:C:2014:2271.

41 See: https://bit.ly/2BkLiQT. 
this trend. ${ }^{42}$ It allowed Member States to temporarily apply "derogatory rules" as regards asylum procedures (extension of time limits, removal of personal interviews), to make use of the possibility under EU law to arrange less demanding reception conditions for asylum seekers, and to adapt the Dublin procedures. At the same time, however, it insisted that fingerprints of all third country nationals should be taken and that, despite the disruption caused by the health crisis, return procedures should continue as far as possible, if needed with the support of Frontex. In the field of irregular migration, the lack of insfrastructural capacities in third countries does not constitute a valid ground for protection. ${ }^{43}$

What this means is that migrants are deprived of access to the infrastructural conditions of living offered to European citizens. Under EU Covid-19 law, migrants are not considered structurally vulnerable persons. To get protected, they can only rely on particular forms of personal vulnerability. ${ }^{44}$

\section{THE FUTURE OF INFRASTRUCTURAL EUROPE}

It may be that infrastructural Europe is a time-limited endeavour designed to respond to a unique outbreak. It is certainly a precarious project. This is so in two aspects. I will briefly conclude with this.

The first aspect to mention is global vulnerability. This crisis has exposed our dependency on external infrastructures, understood complexly as global supply value chains, digital equipment, essential industries and world trade patterns. The Union's institutions long embraced the vision of an open and globalised world. However, the Commission recently became aware of the downsides of this and, perhaps more importantly, of the increasing popular challenges to it (European Commission, 2017). Yet, it has so far maintained its commitment to "free and fair trade." 45 It is clear that, in the present context, "the debate on strategic autonomy and European sovereignty is returning with a vengeance, and in much more practical terms" (Editorial Comments, 2020). This debate is not new. It discreetly unfolded over the last decade

42 Communication from the Commission COVID-19: Guidance on the implementation of relevant $\mathrm{EU}$ provisions in the area of asylum and return procedures and on resettlement (2020/C 126/02), 17 April 2020.

43 See, in particular, Judgment of the Court of 24 April 2018, MP, C-353/16 EU:C:2018: 276. Contrast with Judgment of 9 October 2014, Petru, C-268/13.

44 The EU Guidance indicates that particular attention is due to "people with disabilities, elderly or people with existing health concerns."

45 Art. 3(5) TEU. 
in relation to fields such as defence, energy and technology. But in today's Europe it resounds with force and greater magnitude. On the one hand, the European leaders clearly declare their willingness to "contribute to the EU's strategic autonomy" (Joint statement of the members of the European Council, 26 March 2020). Thus, they welcome the Commission guidelines on screening of direct investment ${ }^{46}$ the White Paper on foreign subsidies in the Single Market, ${ }^{47}$ and a toolbox including a "New Industrial Strategy for Europe", a new Union's trade policy and new competition law instruments. On the other hand, however, the European leaders keep insisting that "the EU commits to international cooperation and multilateral solutions in tackling the pandemic and its consequences." ${ }^{48}$ As repeated by the Commission, "we will always be committed to open and fair trade" (European Commission, 2020c). The assumption is that "Europe will pursue a model of open strategic autonomy".

Europeans do not live comfortably with this dual language. Today's Europeans are subject to colliding temptations. One is to "break their chains" and engage in deglobalisation. The other is to suggest a transformation of the parameters within which infrastructures function in Europe. This is the option favoured by the Commission: the recovery instrument called Next Generation $E U$ is presented as a decisive step towards the building of "a fairer, greener and more digital Europe." (European Commission, 2020c). The Commission focuses on the building of sustainable infrastructures, the strengthening of European value chains and on greater support to Member States' public health and social protection systems.

Whatever one's preference, it seems to me that the most important task facing us, EU lawyers, is to take as an object of study the complex set of interdependences and interconnections Europeans are embedded into, and pinpoint the many ways in which law operates within it. Only this kind of work can allow one to reflect quietly and seriously on wanted and unwanted chains (Latour, 2020). Only then can we imagine new infrastructural designs.

The second aspect concerns the representation of Europe and the precariousness of its anchoring in society. Today's Europe is not just the object of

46 See European Commission, Guidance to the Member States concerning foreign direct investment and free movement of capital from third countries, and the protection of Europe's strategic assets, ahead of the application of Regulation (EU) 2019/452 (FDI Screening Regulation), C(2020) 1981 final, 25 March 2020.

47 See European Commission, White paper on levelling the playing field as regards foreign subsidies, COM(2020) 253 final, 17 June 2020.

48 See also Council of the European Union, The global response: Working together to help the world get better, 2 May 2020. 
objective representations, conveyed by institutions, policies and official symbols. It is the object of subjective representations, that is, acts of appreciation and contestation. It generates social passions and forms of affective polarisation (Azoulai, 2020). Any objective characteristic of the Union and its law is therefore bound to be "subjectivised" and will function either as a rallying sign or as a stigma. ${ }^{49}$ In this context, the notion of infrastructural Europe, in that it heavily relies on institutional support and complex legal mechanisms, may hardly be seen as something meaningful to people. Reconstruction of infrastructures and recovery plans may have been seen as binding ideals and compelling projects to Europeans in post-war Europe. This is no longer the case. Plans are not inspiring to Europeans of our times. Therefore, the challenge for us, EU scholars, may well be to make people aware of the infrastructural conditions on which their existence depend, and in so doing to make them reflect on them and take them as an aim of mobilisation (whether to suggest changes or to contest them altogether).

\section{Bibliography}

Alemanno, A. (2020) The European Response to COVID-19: From Regulatory Emulation to Regulatory Coordination? European Journal of Risk Regulation, 11 (2), 307-316. Available at: https://doi.org/10.1017/err.2020.44.

Azoulai, L. (2018). Le droit européen de l'immigration, une analyse existentielle. Revue trimestrielle de Droit Européen, 54 (3), 519-539.

- (2020). The Madness of Europe, Being Attached to It. German Law Journal, 21 (1), 100-103. Available at: https://doi.org/10.1017/glj.2019.104.

Butler, J. (2020). Mourning is a Political Act Amid the Pandemic and its Disparities. Thruthout, 30-4-2020. Available at: https://bit.ly/2VsflHA.

Confravreux, J. (2019). Le fond de l'air est jaune. Comprendre une révolte inédite. Paris: Seuil.

Dani, M., Mendes, J., Menendez, A. J., Wilkinson, M., Schepel, H., Chiti, E. (2020). At the End of the Law. Verfassungsblog, 15-5-2020. Available at: https://verfassungsblog.de/at-the-end-of-the-law/.

De Witte, F. (2018). Interdependence and Contestation in European Integration. European Papers, 3 (2), 475-509.

49 This is exemplified by the recent decision issued by the German Federal Constitutional Court on the Public Sector Purchase Programme of the European Central Bank (Judgment of 5 May 2020). The decision has been seen as "an affront to the core of EU constitutionalism" (Avbelj, M., The Right Question about the FCC Ultra Vires Decision, Verfassungsblog, 6 May 2020). 
Editorial Comments (2017). EU law as a way of life. Common Market Law Review, 54 (2), 357-367.

Editorial Comments (2020). Disease and recovery in (COVID-afflicted) Europe. Common Market Law Review, 57 (3), 619-630.

Edwards, P. N. (2003). Infrastructure and Modernity: Force, Time, and Social Organization in the History of Sociotechnical Systems. Modernity and Technology, 1, 185-226.

Edwards, P. N. et al. (2013). Knowledge Infrastructures: Intellectual Frameworks and Research Challenges. Ann Arbor: Deep Blue.

Eichler, H. G. et al. (2020). Clinical Trials for COVID-19: Can We Better Use the Short Window of Opportunity? Clinical Pharmacology \& Therapeutics. Available at: https://doi.org/10.1002/cpt.1891.

Elias, N. (2001). The Society of Individuals. London: Continuum.

European Commission (2010). Europe 2020: A Strategy for Smart, Sustainable and Inclusive Growth. Brussels: European Commission. Available at: http://hdl.voced. edu.au/10707/89925.

- (2017). Reflection Paper on Harnessing Globalisation. Brussels: European Commission. Available at: https://bit.ly/31 rasYQ.

- (2020a). Guidelines for border management measures to protect health and ensure the availability of goods and essential services. Brussels: European Commission.

- (2020b). Temporary Restriction on Non-Essential Travel to the EU. Brussels: European Commission.

- (2020c). Europe's moment: Repair and Prepare for the Next Generation. Brussels: European Commission. Available at: https://bit.ly/3i7WnWd.

European Union Agency for Fundamental Rights (FRA) (2020). Migration: Key Fundamental Rights Concerns (1 January 2020 to 31 March 2020). Quarterly Bulletin, 2.

Genestier, P. (2019). Les "gilets jaunes" : une question d'autonomie autant que d'automobile, Le Débat, 204, 16-34. Available at: https://doi.org/10.3917/ deba.204.0016.

Glaser, S. (forthcoming). L'Union européenne, une infrastructure vitale ? Enquête sur le droit de la production des connaissances scientifiques en temps de crise. Le monde d'aujourd'hui. Paris: Presses de Sciences Po.

Hugrée, C., Penissat, É., Spire, A. (2017). Les classes sociales en Europe. Tableau des nouvelles inégalités sur le vieux continent. Paris: Agone.

Joerges, C. (2014). Europe's Economic Constitution in Crisis and the Emergence of a New Constitutional Constellation. German Law Journal, 15 (5), 985-1027. Available at: https://doi.org/10.1017/S2071832200019234.

Joly, M. (2007). L'Europe de Jean Monnet. Paris: CNRS.

Latour, B. (2020). Imaginer les gestes-barrières contre le retour à la production d'avant-crise. $A O C$ [blog], 31-3-2020. Available at: https://bit.ly/38asDmH.

Marzal, T. (2020). From World Actor to Local Community: Territoriality and the Scope of Application of EU Law. SSRN, 31-3-2020. Available at: https://doi. org/10.2139/ssrn.3549281. 
INFRASTRUCTURAL EUROPE: EU LAW AND HUMAN LIFE IN TIMES OF THE COVID-19... 359

Pacces, A. M. and Weimer, M. (2020). From Diversity to Coordination: A European Approach to COVID-19. European Journal of Risk Regulation, 11 (2), 283-296. Available at: https://doi.org/10.1017/err.2020.36.

Steiert, M. (2019). Youth Lost in Crisis? Interactions between EU Law and the Youth in the Euro-Crisis. Master Dissertation, Sciences Po Law School (Paris).

Thym, D. (2020). Travel Bans in Europe: A Legal Appraisal. Verfassungsblog, 19-32020. Available at: https://verfassungsblog.de/travel-bans-in-europe-a-legalappraisal/.

Walker, N. (2017). The European Public Good and European Public Goods. Manuscript available from the author. 
